\title{
SEGMENTS OF COMPETITION IN SOUTH BRAZILIAN WINERIES
}

\author{
Marcelo Miele $^{1 *}$; Arlei Coldebella ${ }^{1}$; Paulo Dabdab Waquil²; Alberto Miele ${ }^{3}$ \\ ${ }^{1}$ Embrapa Suínos e Aves, BR 153, Km 110 - 89700-000 - Concórdia, SC - Brasil. \\ ${ }^{2}$ UFRGS/FCE/DE, Av. João Pessoa, 31 - 90040-000 - Porto Alegre, RS - Brasil. \\ ${ }^{3}$ Embrapa Uva e Vinho, R. Livramento, 515 - 95700-000 - Bento Gonçalves, RS - Brasil. \\ *Corresponding author <mmiele@cnpsa.embrapa.br>
}

\begin{abstract}
The international restructuring process in the beverage sector reached the winemaking business in the 1990s, changing its panorama. Increasing competitive pressure is a characteristic of this period with significant impact in regions such as the countries belonging to the Mercosul block. To support firm strategies and public policies, the goal of this study was to identify the competition segments in winemaking in Rio Grande do Sul, the southern state of Brazil, and in a specific form to propose a typology of wineries based on the Industrial Organization literature. The data used are from the State Wineries Data Bank of Rio Grande do Sul, which were submitted to multivariate statistical analysis, integrating a cluster and principal components analysis in a group of 381 observations. The results showed the existence of two factors, one related to scale and diversification, and the other related to the quality of the products and of the raw material. From these factors, six groups of wineries were identified that can be named segments of competition in winemaking. Group 1 is characterized by quality and specialization; group 2, by a large production scale and diversification; group 3, by a low added value; group 4, by a micro production scale; and groups 5 and 6, by a low added value, small scale, and specialization.
\end{abstract}

Key words: agribusiness, diversification, scale, typology, wine

\section{SEGMENTOS DE COMPETIÇÃO EM VINÍCOLAS DO SUL DO BRASIL}

\begin{abstract}
RESUMO: O processo de reestruturação internacional no setor de bebidas atingiu a vitivinicultura na década de 1990, alterando o seu panorama. Característico a esse período é o aumento da pressão competitiva, com impactos significativos em regiões como a dos países membros do Mercosul. Para apoiar as estratégias empresariais e as políticas públicas, o objetivo deste estudo foi identificar os segmentos de concorrência da vitivinicultura do Rio Grande do Sul e, de forma específica, propor uma tipologia das vinícolas gaúchas com base na literatura da Organização Industrial. Utilizaram-se os dados do Cadastro Vinícola do Rio Grande do Sul os quais foram submetidos à análise estatística multivariada, integrando análises de agrupamento e de componentes principais em um conjunto de 381 observações. Os resultados apontaram para a existência de dois fatores, um relacionado à escala e diversificação e o outro à qualidade dos produtos e da matéria-prima. A partir desses fatores, foram identificados seis grupos de vinícolas que podem ser denominados de segmentos de concorrência na vitivinicultura gaúcha. O grupo 1 se caracteriza pela qualidade e especialização; o 2, pela grande escala de produção e diversificação; o 3, pelo baixo valor agregado; o 4, pela micro escala de produção; e os grupos 5 e 6, pelo baixo valor agregado, pequena escala e especialização.

Palavras-chave: agronegócio, diversificação, escala, tipologia, vinho
\end{abstract}

\section{INTRODUCTION}

Brazil holds the $17^{\text {th }}$ position in the international wine scenario, with $1.2 \%$ of the produced volume (Anderson et al., 2001), the southern state of Rio Grande do Sul being responsible for about $90 \%$ of the production. The national market is considered small with a low per capita consumption. The classification determined by the Brazilian legislation allows the identification of more than 25 products derived from grape and wine (from sparkling wine to vinegar), however the production of low added value products predominates, like table wine and concentrated grape juice. Besides this, it is emphasized that half of the volume is commercialized in bulk, reinforcing the commodity characteristic of the production, although the predomination of bottling in some products such as quality wine and sparkling wine (Miele, 2004). From 437 winemakers which commercialized wine and other derivatives from wine and grape in the year of this re- 
search (2002), only 103 were quality wine and 32 sparkling winemakers.

Thus, the profile of this production contrasts with the competitive international environment which was outlined in the 1990s, when companies developed a range of products of superior quality, nearly always orientated to larger consumer markets through wellknown brands (Anderson et al., 2001; Green \& Santos, 2002). This difference between the positioning of the sector in Brazil and the international market trend reflects the low export performance as well as the competition of imported wine in the higher added value segment (Miele, 2004). In fact, the share of imported wine in the total consumption of quality products in Brazil went from 41\% in 1998 to 65\% in 2004 (Uvibra, 2005). This effective threat points to the need of reflection about strategic decisions of the companies and cooperatives, as well as the formulation of public policies or collective actions. To support them, the goal of this study was to identify segments of competition in winemaking in the state of Rio Grande do Sul, and in a specific form, to propose a typology of wineries from their market structure and conduct characteristics based on data from the State Wineries Data Bank, year 2002 (Mello, 2001; Cadastro, 2002).

\section{MATERIAL AND METHODS}

There are many methodological and theoretical approaches which try to explain the nature, the growth, and the limits of the firms, besides the market structures and the competitive ambient. The present study has as theoretical referential the Industrial Organization (IO), which characterizes an industry competition from the market structure where the firms (producers and buyers) are inserted, the different strategies adopted by them, the performance and the institutional and technological environment (Scherer \& Ross, 1990; Farina et al., 1997).
In this paradigm, named Structure-ConductPerformance (SCP), a market structure is characterized by different variables, like number of the producers and buyers, their scale of production and market participation, the product differentiation, cost structure, and the geographical and sectorial diversification of the firms (Scherer \& Ross, 1990). The SCP literature is complemented with chain and agri-systems analysis, like the Commodity System Approach (CSA), which explores the vertical relationship between the different phases of production and marketing, and the organizational and geographical extension of the supply and distribution chain (Goldberg, 1968; Zylberstajn, 1995; Zylberstajn \& Farina, 1998). Britto (2002) points out to the need of verifying the possible diversification directions (horizontal, vertical, and concentric) and forms (investments in new capacities, fusions, and acquisitions). Variables as segmentation, diversification, and differentiation are not only considered as market structure characteristics but also as indicatives of the strategies adopted by the firms (Farina et al., 1997; Mintzberg \& Quinn, 1998; Britto, 2002).

The possibility to analyze multiple variables is interesting for this study. Together, these variables characterize the structure and the strategies in the South Brazilian wine industry, which permit, even though partially, a better understanding of the different segments of competition in this industry. The source of data for this study is the State Wineries Data Bank of Rio Grande do Sul - 2001-2002, which can be used as proxies for the theoretical IO variables, as shown in Table 1, leading to a multivariate winery typology and market structure characterization.

The State Wineries Data Bank of Rio Grande do Sul was developed by the Enology Division of the State Secretary of Agriculture and the Brazilian Wine Institute - Ibravin (Mello, 2001; Cadastro, 2002). From the legal point of view, wineries are responsible to pre-

Table 1 - Description of the variables.

\begin{tabular}{|c|c|c|c|}
\hline Theoretical variable & & Proxy used & Name \\
\hline Production scale & & Total commercialized volume & SCALE \\
\hline \multirow{2}{*}{$\begin{array}{l}\text { Geographical } \\
\text { extension of the } \\
\text { value chain }\end{array}$} & Distribution & Sales outside Rio Grande do Sul (\%) & SALESEXTENT \\
\hline & Supply & Purchases outside the district $(\%)$ & SUPPLYEXTENT \\
\hline \multirow{3}{*}{ Quality } & Product & Products with added value (\%) & ADDEDVALUE \\
\hline & \multirow[t]{2}{*}{ Raw material } & Measure of sugar in the acquired grapes & SUGAR \\
\hline & & Vitis vinifera grapes from the total acquired (\%) & VINIFERA \\
\hline \multirow{4}{*}{ Diversification } & \multirow[t]{2}{*}{ Products } & Number of products from the winery & NPRODUCTS \\
\hline & & Concentration ratio of the two most importants products & CRPRODUCTS \\
\hline & \multirow[t]{2}{*}{ Markets } & Number of destinies & NDESTINIES \\
\hline & & Concentration ratio of the two most importants destinies of sales & CRDESTINY \\
\hline
\end{tabular}


pare an annual report which is the base for the referred data bank. Actually, it is an important instrument for the state agricultural policy directed to wine control and inspection. Besides, due to the amount of information, it presents useful data for economic and organizational studies in winemaking.

The sales volume of wine and derivatives of grape and wine is considered a scale proxy, and it is named SCALE. The percentage of sales of the winery outside the state of origin is a proxy for the geographical extension of the distribution chain, and it is named SALESEXTENT. The percentage of purchase of raw material outside the winery district is considered a proxy for the geographical extension of the supply chain, and it is named SUPPLYEXTENT.

The quality of the wine and products derived from wine and grape can be quantified through laboratory and sensory analysis. Besides the difficulty in operating this procedure to all wineries, subjective aspects and cultural influences have to be considered when analyzing consumer choices. Therefore, it was chosen to define the quality of the product from some easily checkable and objective characteristics related to the added value of the product. This variable is named ADDEDVALUE, and it is measured as the proportion of higher added value sales in the total volume of sales, which is considered a proxy to the extent to which the winery competes in better quality segments. Added value sales are bottled wines (in bottles until $750 \mathrm{~mL}$ ) produced with Vitis vinifera grapes, bottled grape juice (in bottles until $750 \mathrm{~mL}$ ), sparkling wine, and bottled cooler (in bottles until $750 \mathrm{~mL}$ ). To define the quality of the raw material, two indicators were used, i.e., the average sugar concentration of acquired grapes, named SUGAR, and the proportion of Vitis vinifera grapes and the total acquired grapes, named VINIFERA.

The degree of diversification of winery products was measured from two indicators. The first is the number of products of the winery, named NPRODUCTS and the second is the proportion of sales of the two main products in the total sales (a kind of concentration ratio-CR), which is named CRPRODUCTS. It was considered as different products the combination of three dimensions used in the data bank, which are: product (wine, sparkling wine, vinegar, juice etc.), classification (vinifera, table, sweetened etc.), and type (white, red, rosé). The difference in type of packaging was not considered as this dimension is considered in variable ADDEDVALUE. The degree of the diversification of sale destinies was measured from two indicators. The first is the number of destinies supplied by the winery, named NDESTINIES. The other one is the proportion of the two main destinies in the total sales (a kind of concentration ratio-CR), which is named CRDESTINY. Destiny should be understood as the number of supplied states (political division in Brazil) plus the foreign markets.

Analyzed in group, the variables SALESEXTENT, SUPPLYEXTENT, NDESTINIES and CRDESTINY can also lead to the organizational extension of the supply chain, since supplying for a larger number of markets and from a larger number of producers implies in a more complex structure and skills in sales, marketing, purchases and logistics.

Quantitative techniques were used to investigate 381 observations corresponding to the analyzed universe. Initially, average, standard deviation, and minimum and maximum values were calculated for each variable, in order to obtain a summary of the information and to identify possible great differences regarding the variability of the variables. From this information, variables were standardized and data were evaluated trough principal component analyses and cluster analyses. The principal component analysis was used to better understand the results issued from the cluster analysis. Discriminated winery groups were validated through analysis of variance and the Tukey test.

\section{RESULTS AND DISCUSSION}

There is a great variation among the observations (Table 2), mostly for the variables SCALE, NDESTINIES, and NPRODUCTS.

The correlation matrix of the standardized data in Table 3 and the principal component analysis in Figure 1 indicate the existence of two factors, which explain $59.3 \%$ of the variations. The first can be named 'scale and diversification'. The variables SCALE, NDESTINIES, and NPRODUCTS are closely related, which is explained by the need of diversification in larger scale wineries. For the same reason, these variables are also partially associated to the variable SALESEXTENT. Since a larger scale of production requires an effort in obtaining raw material from districts other than the company headquarters, these variables are also associated to SUPPLYEXTENT. Besides, these variables are partially associated to ADDEDVALUE, SUGAR, and VINIFERA, which indicates that larger scale and diversified wineries encompass higher added value in a wide range of products. The inverse relation between the variables NPRODUCTS and CRRODUCTS and between NDESTINIES and CRDESTINY indicates that the larger the diversification the smaller the concentration in sales of a certain product or market. 
Table 2 - Descriptive statistics of the nine variables related to 381 South Brazilian wineries.

\begin{tabular}{lcccc}
\hline Variables* & Average & Standard Deviation & Minimum & Maximum \\
\hline CRDESTINY & $85 \%$ & $16 \%$ & $44 \%$ & $100 \%$ \\
CRPRODUCTS & $95 \%$ & $10 \%$ & $48 \%$ & $100 \%$ \\
SUPPLYEXTENT & $21 \%$ & $28 \%$ & $0 \%$ & $100 \%$ \\
SALESEXTENT & $82 \%$ & $31 \%$ & $0 \%$ & $100 \%$ \\
SUGAR & 14.5 & 0.9 & 12.0 & 19.1 \\
NDESTINIES & 5.5 & 6.0 & 1.0 & 28.0 \\
NPRODUCTS & 2.9 & 2.7 & 1.0 & 18.0 \\
SCALE (in thousands) & 756 & 2,371 & 0.01 & 26,592 \\
VINIFERA & $10 \%$ & $24 \%$ & $0 \%$ & $100 \%$ \\
ADDEDVALUE & $7 \%$ & $22 \%$ & $0 \%$ & $100 \%$ \\
\hline
\end{tabular}

Source: State Wineries Data Bank of Rio Grande do Sul, 2002. *Variables description is in Table 1.

Table 3 - Correlation matrix of scale proxies with standardized data.

\begin{tabular}{|c|c|c|c|c|c|c|c|c|c|}
\hline Variables* & SCALE & SALESEXTENT & Г ADDEDVALUE & NPRODUCTS & CRPRODUCTS N & JDESTINIES C & RDESTINY & SUGAR & VINIFERA \\
\hline SALESEXTENT & 0.06 & & & & & & & & \\
\hline ADDEDVALUE & 0.07 & -0.29 & & & & & & & \\
\hline NPRODUCTS & 0.60 & -0.22 & 0.23 & & & & & & \\
\hline CRPRODUCTS & -0.39 & 0.32 & -0.32 & -0.72 & & & & & \\
\hline NDESTINIES & 0.49 & -0.05 & 0.49 & 0.74 & -0.54 & & & & \\
\hline CRDESTINY & -0.24 & -0.16 & -0.21 & -0.37 & 0.25 & -0.62 & & & \\
\hline SUGAR & 0.15 & -0.36 & 0.55 & 0.24 & -0.21 & 0.35 & -0.09 & & \\
\hline VINIFERA & 0.05 & -0.26 & 0.85 & 0.22 & -0.27 & 0.45 & -0.15 & 0.59 & \\
\hline SUPPLYEXTENT & 0.26 & -0.20 & 0.29 & 0.37 & -0.30 & 0.42 & -0.13 & 0.36 & 0.33 \\
\hline
\end{tabular}

Source: State Wineries Data Bank of Rio Grande do Sul, 2002. *Variables description is in Table 1.

Factor 2 (Quality) - $18.6 \%$

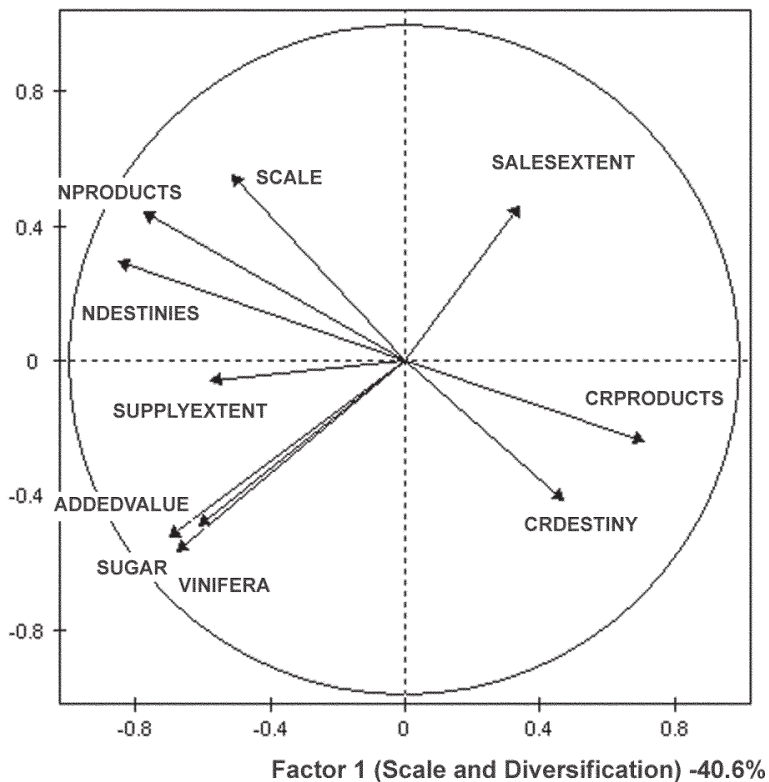

Figure 1 - Representation of the principal component analysis of the nine variables of 381 South Brazilian wineries, where the factor 1 represented $40.6 \%$ and the factor $218.6 \%$ of the total variation.
The second identified factor can be named 'quality'. The variables ADDEDVALUE, SUGAR, and VINIFERA are closely related, which is explained by the fact that products of higher quality have multiple attributes like packaging in bottles, type of product, and type and quality of the raw material. These variables are also associated to the variable SUPPLYEXTENT, indicating that a quest for quality is linked to an effort in obtaining raw material in districts other than the headquarters of the company. On the other hand, this group of variables is in opposition to the variable SALESEXTENT, indicating that the quality of the product is associated to the local retail, with a smaller geographical scope.

The cluster analysis pointed to six winery groups in Rio Grande do Sul, according to the dispersion among the two factors shown in Figure 2, and the average test among the groups in Table 4 . From this analyses it is possible to characterize six winery groups which can be called strategic segments in winemaking in the state of Rio Grande do Sul. 


\section{Group description}

Group 1 is made up of 30 wineries, one being a public stock company, three multinational companies in the beverage sector, and none of them a cooperative.

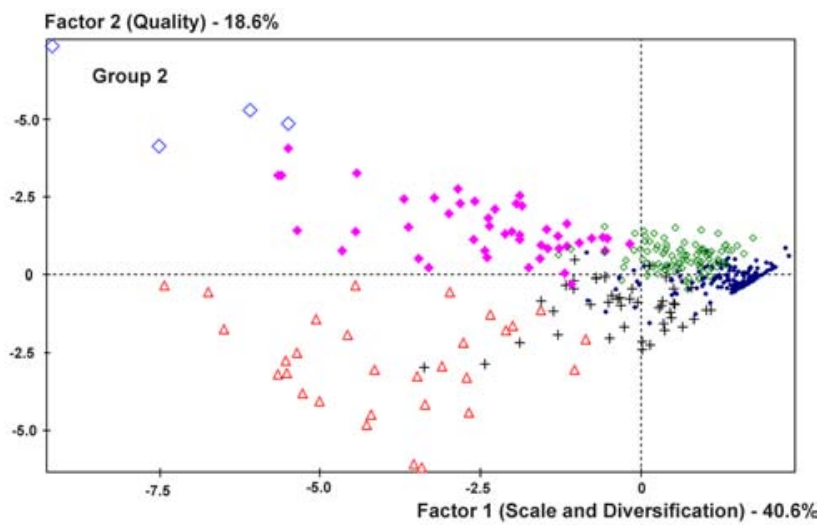

Figure 2 - Dispersion of observations of 381 South Brazilian wineries between the first two factors of the principal component analysis, where the factor 1 represented $40.6 \%$ and the factor $218.6 \%$ of the total variation.
This group represents $6.5 \%$ of the commercialized volume of wine and derivatives from wine and grape, and $7.9 \%$ of the number of wineries. However, it concentrates the production of sparkling wine and quality wine, with $52.2 \%$ and $46.9 \%$ of the total sales in volume of these items, respectively, as shown in Tables 5 and 6.

The companies in group 1 , have in general a medium and large scale, but there are some exceptions of small wineries. In larger scale wineries, the distribution has a national scope, and in the medium and small wineries of the group the local market has a significant importance. The supply of raw material is regional, with an effort in finding quality grapes in communes other than the headquarter of the company. This should enable larger scales of production and points to an organizational effort in obtaining raw material. The cases which essentially present local supply of raw material refer to some medium and small wineries, or companies located in communes with large land extensions in the south of the state, outside the traditional producing region, where small farms predominate.

Table 4 - Group means and Tukey test of the evaluated variables.

\begin{tabular}{lcccccc}
\hline Variables* & \multicolumn{5}{c}{ Group } \\
\hline & 1 & 2 & 3 & 4 & 5 & 6 \\
\hline N. $^{\circ}$ wineries & 30 & 4 & 46 & 43 & 149 & 109 \\
CRDESTINY & $80 \% \mathrm{~b}$ & $59 \% \mathrm{c}$ & $73 \% \mathrm{~b}$ & $97 \% \mathrm{a}$ & $97 \% \mathrm{a}$ & $73 \% \mathrm{~b}$ \\
CRPRODUCTS & $89 \% \mathrm{~b}$ & $67 \% \mathrm{c}$ & $85 \% \mathrm{~b}$ & $91 \% \mathrm{~b}$ & $100 \% \mathrm{a}$ & $99 \% \mathrm{a}$ \\
SUPPLYEXTENT & $43 \% \mathrm{a}$ & $49 \% \mathrm{a}$ & $50 \% \mathrm{a}$ & $28 \% \mathrm{ab}$ & $16 \% \mathrm{~b}$ & $7 \% \mathrm{~b}$ \\
SALESEXTENT & $55 \% \mathrm{~b}$ & $86 \% \mathrm{a}$ & $86 \% \mathrm{a}$ & $11 \% \mathrm{c}$ & $99 \% \mathrm{a}$ & $94 \% \mathrm{a}$ \\
SUGAR & $16.1 \mathrm{a}$ & $15.2 \mathrm{~b}$ & $14.7 \mathrm{bc}$ & $14.8 \mathrm{bc}$ & $14.1 \mathrm{c}$ & $14.2 \mathrm{c}$ \\
NDESTINIES & $12.7 \mathrm{~b}$ & $23.8 \mathrm{a}$ & $14.9 \mathrm{~b}$ & $2.7 \mathrm{c}$ & $2.0 \mathrm{c}$ & $4.9 \mathrm{c}$ \\
NPRODUCTS & $4.1 \mathrm{c}$ & $14.8 \mathrm{a}$ & $7.2 \mathrm{~b}$ & $3.4 \mathrm{~cd}$ & $1.4 \mathrm{e}$ & $2.3 \mathrm{de}$ \\
SCALE (in thousands) & $628 \mathrm{c}$ & $18.341 \mathrm{a}$ & $2.720 \mathrm{~b}$ & $116 \mathrm{c}$ & $185 \mathrm{c}$ & $349 \mathrm{c}$ \\
VINIFERA & $86 \% \mathrm{a}$ & $17 \% \mathrm{~b}$ & $11 \% \mathrm{bc}$ & $4 \% \mathrm{~cd}$ & $2 \% \mathrm{~cd}$ & $1 \% \mathrm{~d}$ \\
ADDEDVALUE & $68 \% \mathrm{a}$ & $19 \% \mathrm{~b}$ & $8 \% \mathrm{bc}$ & $7 \% \mathrm{c}$ & $0.1 \% \mathrm{c}$ & $0.1 \% \mathrm{c}$ \\
\hline
\end{tabular}

Source: State Wineries Data Bank of Rio Grande do Sul, 2002. Means followed by distinct letters in the lines differ by the Tukey test $(P<0.05) . *$ Variables description is in Table 1.

Table 5 - Market share of the groups per sale volume.

\begin{tabular}{lrrrrrr}
\hline Group & \multicolumn{5}{c}{ Commercialization (in thousands liters) } \\
\hline & \multicolumn{7}{c}{ Total } & \multicolumn{2}{c}{ Quality wine } & \multicolumn{2}{c}{ Quality sparkling wine } \\
\hline 1 & 18.852 & $7 \%$ & 11.138 & $47 \%$ & 2.221 & $52 \%$ \\
2 & 73.364 & $25 \%$ & 9.501 & $40 \%$ & 1.497 & $35 \%$ \\
3 & 125.112 & $43 \%$ & 2.804 & $12 \%$ & 533 & $13 \%$ \\
4 & 4.998 & $2 \%$ & 75 & $0.3 \%$ & 0 & $0 \%$ \\
5 & 27.610 & $10 \%$ & 20 & $0.1 \%$ & 0 & $0 \%$ \\
6 & 38.012 & $13 \%$ & 218 & $1 \%$ & 0 & $0 \%$ \\
\hline Total & 287.948 & $100 \%$ & 23.755 & $100 \%$ & 4.251 & $100 \%$ \\
\hline
\end{tabular}

Source: State Wineries Data Bank of Rio Grande do Sul, 2002. 
Table 6 - Market share of the groups per number of wineries.

\begin{tabular}{|c|c|c|c|c|c|c|}
\hline \multirow{3}{*}{$\begin{array}{l}\text { Group } \\
1\end{array}$} & \multicolumn{6}{|c|}{ Number of wineries } \\
\hline & \multicolumn{2}{|c|}{ Total } & \multicolumn{2}{|c|}{ Quality wine } & \multicolumn{2}{|c|}{ Quality sparkling wine } \\
\hline & 30 & $8 \%$ & 30 & $29 \%$ & 17 & $53 \%$ \\
\hline 2 & 4 & $1 \%$ & 4 & $4 \%$ & 4 & $13 \%$ \\
\hline 3 & 46 & $12 \%$ & 35 & $34 \%$ & 11 & $34 \%$ \\
\hline 4 & 43 & $11 \%$ & 16 & $16 \%$ & 0 & $0 \%$ \\
\hline 5 & 149 & $39 \%$ & 3 & $3 \%$ & 0 & $0 \%$ \\
\hline 6 & 109 & $29 \%$ & 15 & $15 \%$ & 0 & $0 \%$ \\
\hline Total & 381 & $100 \%$ & 103 & $100 \%$ & 32 & $100 \%$ \\
\hline
\end{tabular}

Source: State Wineries Data Bank of Rio Grande do Sul, 2002.

Nearly all the wineries in group 1 commercialize products with a higher added value and superior quality raw material, and in general are little diversified in terms of range of products and averagely diversified in terms of geographic markets. However, in some large wineries from this group there is lower added value, above all in relation to the type of packaging (in bulk) and not in relation to the type of product (predominates quality wine in the range of products from these companies). It can be said that the leading companies in the quality products segment are found in this group. In fact, between the 10 first wineries in the quality wine and sparkling wine sales ranking, five are from group 1.

Group 2 is made up of four of the five largest wineries, one of them being a cooperative. They can be said to be leaders in sharing the market, with the cooperative as number one in the list. In total, it represents $25.5 \%$ of the sales volume of wine and derivatives of grape and wine (the largest winery has $9.2 \%$ of the volume), and represents only $1.0 \%$ of the number of wineries. Like the previous group, it represents a significant portion in the sales of sparkling wine and quality wine, with $35.2 \%$ and $40.0 \%$, respectively, as shown in Tables 5 and 6.

Being large wineries, the variable SCALE defines the fitting in the group. The distribution has a national scope and the grape supply is regional, characterizing an effort to assure large volumes or better quality. This should enable larger production scales and points to an organizational effort in obtaining raw material. The cooperative in this group is an exception, essentially presenting local supply of raw material.

This group is essentially characterized by the scale of its components. However, two of the wineries have higher added value products with better quality raw material and product diversification. Because of this, they are similar to some companies in group 1. However, because of the scale and the wide range of products, it is natural to have an ADDEDVALUE percentage inferior to that of group 1. The other two wineries show low added value, low quality, and little diversification in products, similar to the largest wineries in group 3. The wineries in this group are diversified in relation to geographical markets, especially regarding the scale needs.

Group 3 is made up of 46 wineries, nine of them being cooperatives. It represents $43.4 \%$ of the sales of wine and grape and wine derivatives, and $12.1 \%$ of the number of wineries. Large scale wineries predominate, with some medium companies. The distribution has national scope and the supply of raw material is regional. This should enable larger production scales and points to an organizational effort in obtaining raw material. The supply between cooperatives in this group is more local than the other wineries. With some exceptions, these wineries have low added value products and low quality raw material. Also, they are diversified in relation to the range of products and geographical markets. Together with the wineries from group 2, they are leaders in terms of sales volume of table wine and cooler.

Group 4 is made up of 43 wineries, one of them being a cooperative. It represents only $1.7 \%$ of the sales volume of wine and grape and wine derivatives, and $11.3 \%$ of the number of wineries, as shown in Tables 5 and 6. These wineries are mainly micro companies which fit into what is conventionally called a 'family agroindustry', with essentially local distribution and supply. The products have low added value, with low quality raw material. The wineries in this group are specialized (not diversified) in relation to the range of products and geographical markets.

Group 5 is made up of 149 wineries, three of them being cooperatives. It represents $9.6 \%$ of the sales volume of wine and grape and wine derivatives, and $39.1 \%$ of the number of wineries as shown in Tables 5 and 6 . The scale is varied, having medium, small, and micro wineries. However, together with group 6, it concentrates the majority of small wineries. The dis- 
tribution is essentially national, with little presence in the local market, indicating subordination to the supply chain of bottling companies from other states, near larger consumer centers as São Paulo and Rio de Janeiro. The supply is essentially local in the majority of the wineries in this group, with exceptions above all in those of larger scale. The products have very low added value, being distributed in bulk. The wineries from this group are specialized (not diversified) in relation to the range of products and geographical markets.

Group 6 is made up of 109 wineries, three of them being cooperatives. It represents $13.2 \%$ of the commercialized volume of wine and grape and wine derivatives, and $28.6 \%$ of the number of wineries as shown in Tables 5 and 6. Its characteristics are similar to group 5, but represent a larger diversification in relation to geographical markets.

\section{Firm strategies, public policies, and research impli- cations}

Wineries of group 1 , and to a certain extent in group 2, have a closer profile to international competition and are more associated to the changes verified through the decade and exposed to the competition of imports. In these groups, the three multinational companies of the beverage sector that act in the country are present, as well the leading wineries in production and commercialization of quality wine, table wine, sparkling wine, cooler, and grape juice.

The challenges of the larger companies in these groups are increase the efficiency of their logistics and the coordination of raw material supply, strength the brand to face large retailers and, in some cases, update processing and packaging technologies. The smaller companies of group 1 have as challenge to develop their competencies in direct sales to the consumer, associated to tourism, possibly exploring local characteristics, in direction to controlled geographical indications. This option seems to be limited to smaller scale companies from group 1, leader organizations that achieve to coordinate actions in different geographical indications, and some cooperatives from groups 2 and 3 which have as a predominant characteristic the local supply of raw material. This cooperative advantage also plays an important role for the local development.

The great diversity in products (wide range) of the wineries of group 2, which encompasses an expressive volume of high as well as low added value products, represents a straight relation between these segments. Although there is a clear distinction among consumers of these products and between distribution channels and grape suppliers, the organizations which process and sale these products are the same. Two sets of challenges arise here. First, the need to have such a diversity of products should be analyzed by winery strategists. Second, the fact that these wineries act in various segments should be considered by public policy makers, who usually focus only on one type of product, misunderstanding the relation among these segments. They should attempt to the set of possibilities allowed by the wineries and by the structure of the grape production, with predomination of American and hybrid varieties and, consequently, the production of table wine. This relation between high and low added value products is also found in group 3, although less expressive. The additional challenge which is put to this group would be to increase the higher added value product share, but not only through those linked to sparkling and quality wine, but through investments in the bottling line of the table wine and product innovations, such as the cooler.

The wineries of group 4, called family agroindustries, are associated to subsistence activities, of little organizational complexity, and management limitations. The challenge of this group is associated to competence in the winery and the vineyard management, as well as enlarging commercializing spaces. In this sense, the outsourcing of supply for medium and large wineries to enlarge scale and have market experience is presented as an alternative to those whose strategic option is growth. The other option for this group is increasing ties with local retailers or joining a tourist route, both with implications to sale skills.

The wineries in groups 5 and 6 are subordinated to supply strategies of other wineries and bottling companies, most of them located in the main consumer centers of the country. One of the main challenges that arises from this bulk distribution channel is the need for inspection and control not only in the state of Rio Grande do Sul, but with the same severity in other states. This strict inspection and control not only qualifies the relation between wineries in group 5 and 6 and their commercial partners, but also would avoid the possibility of disloyal competition from the bottling companies in relation to wineries from groups 2 and 3. Considerations in relation to the range of products and higher added value pointed out to group 3 are also valid for the wineries of this group.

Lastly, as mentioned earlier by Miele (2004), the State Wineries Data Bank of Rio Grande do Sul provides a richness of data which can be useful not only for inspection but also for research and chain management. The challenge facing the researchers is to evaluate the validity of the proxies used (i.e., to establish operational measures adequate to the theoretical concepts which are being studied), as well as how to articulate these data to other sources such as the 
Viticulture Data Bank of Rio Grande do Sul and bases developed through specific research (Freire et al., 1992; Miele, 2000; Fensterseifer et al., 2003). It is believed that this articulation and new studies enable to qualify the characterization of wine producers adding to the present analysis proxies to theoretical variables here absent, such as institutional and organizational dimensions, and cost and profit measures.

\section{CONCLUSIONS}

There is a discrepancy between the recent developments in worldwide winemaking and the profile of production in Brazil. Because of this, it is considered important to identify segments of competition to evaluate its potential competition facing increasing imported products. From a theoretical point of view, it is supposed that understanding the ways of production and distribution of goods has to map elements proposed through the SCP paradigm and the CSA approach. In this way, it is believed that this study might be useful in proposing a typology of the winemaking companies and cooperatives, based on some of its microeconomic characteristics.

In the South Brazilian wineries, an increase in the production scale requires a larger geographical diversification, considering both sale destinies and raw material supply. Otherwise, the great scale of production is not necessarily associated to the product differentiation, because there are large and specialized wineries of which the main focus is a narrow range of products. The quality is associated to a strategy of specialization in terms of the range of products, and, in the case of the smaller wineries, to local supply and distribution. Otherwise, the low quality is verified in different dimensions and degrees of diversification or specialization, which is not a characteristic of a specific organization format. Nevertheless, it is strongly associated to a strategy disconnected from the local market and dependent on the bulk distribution. Six groups of winemaking companies were identified, with a great diversity in strategies and organizations, presenting different challenges for strategic options and public policies. Group 1 is characterized by quality and specialization; group 2, by a large production scale and diversification; group 3 , by a low added value; group 4 , by a micro production scale; and groups 5 and 6 , by low added value, small scale, and specialization.

\section{ACKNOWLEDGEMENTS}

To Mr. Plinio Manosso, head of the Enology Division of the Agricultural Secretary (DE/DPV/SAARS); Mr. Carlos Paviani, Executive President of the
Brazilian Wine Institute - Ibravin; and Mr. Juliano Corteze, for their support and attention; to Miss Carolina Talamini, for her contribution to the English text.

\section{REFERENCES}

ANDERSON, K.; NORMAN, D.; WITTWER, G. Globalization and the world's wine markets: overview. Adelaide: Adelaide University, 2001. (CIES Discussion Paper, 143).

BRITTO, J. Diversificação, competências e coerência produtiva. In: KUPFER, D.; HASENCLEVER, L. (Org.). Economia industrial: fundamentos teóricos e práticas no Brasil. Rio de Janeiro: Campus, 2002. 680p.

CADASTRO Vinícola do Rio Grande do Sul: 2001/2002. Versão 1.0.Bento Gonçalves: Divisão de Enologia/DPV/SAA; Ibravin, 2002. 1 CD-ROM.

FARINA, E.M.M.Q.; AZEVEDO, P.F.; SAES, M.S.M. Competitividade: mercado, Estado e organizações. São Paulo: Singular, 1997. 286p.

FENSTERSEIFER, J.E.; LOCKMANN, M.E.; ALIEVI, R.M.; WILK, E.O.; MIELE, M.; PEDROZO, E.A. Estratégias de produção e distribuição na indústria vinícola: opções estratégicas para as empresas brasileiras e o papel da cooperação inter-firma. Porto Alegre: UFRGS, 2003. 74p. (Relatório de Projeto de Pesquisa do CNPq).

FREIRE, L.M. de M.; FREIRE, J. de M.; CALDART, W.L. Transformações na estrutura produtiva dos viticultores da Serra Gaúcha 1985/1991. Bento Gonçalves: EMBRAPA, CNPUV, 1992. 44p. (Documentos, 7).

GOLDBERG, R.A. Agribusiness coordination: a system approach to the wheat, soybean, and Florida orange economies. Cambridge: Harvard University, 1968. 256p.

GREEN, R.; SANTOS, R.R. El mercado mundial del vino: perspectivas para Brasil. Bento Gonçalves: Vino Brasil, 2002.

MELLO, L.M.R. de. (Ed.). Cadastro Vitícola do Rio Grande do Sul: 1995/2000. Versão 1.0.Bento Gonçalves: Embrapa Uva e Vinho: Ibravin, 2001. 1 CD-ROM.

MIELE, M. Análise da transação entre produtores de uva e agroindústria vinícola: o caso dos vinhos finos no sistema agro-industrial vitivinícola do Rio Grande do Sul. São Paulo: FEA/USP, 2000. 109p. (Dissertação - Mestrado).

MIELE, M. Análise do Cadastro Vinícola do Rio Grande do Sul para um processo inicial de caracterização do sistema agroindustrial vitivinícola gaúcho. In: CONGRESSO BRASILEIRO DE ECONOMIA E SOCIOLOGIA RURAL, 42., Cuiabá, 2004. Dinâmicas setoriais e desenvolvimento regional: anais. Cuiabá: Sociedade Brasileira de Economia e Sociologia Rural, 2004. p.1-14.

MINTZBERG, H.; QUINN, J.B. O processo da estratégia. Porto Alegre: Bookman, 1998. 404p.

SCHERER, F.; ROSS, D. Industrial market structure and economic performance. Boston: Houghton Mifflin, 1990. 713p.

UNIÃO BRASILEIRA DE VITIVINICULTURA. Dados de produção e comercialização de vinhos e compilação da legislação pertinente. Disponível em: <www.uvibra.com.br>. Acesso em: 14 mar. 2005.

ZYLBERSZTAJN, D. Estruturas de governança e coordenação do agribusiness: uma aplicação da nova economia das instituições. São Paulo: FEA/USP, 1995. 237p. (Tese - Livre-Docência).

ZYLBERSZTAJN, D.; FARINA, E.M.M.Q. Agry-system management: recent developments and applicability of the concept. In: INTERNATIONAL CONFERENCE ON CHAIN MANAGEMENT IN AGRIBUSINESS AND THE FOOD INDUSTRY, 3., Wageningen, 1998. Proceedings. Wageningen: Wageningen Academic Publishers, 1998. p.679-689.

\footnotetext{
Received April 17, 2006
}

Accepted March 26, 2007 